DEPARTMENT OF THE INTERIOR

U.S. GEOLOGICAL SURVEY

\title{
SLOPE MAP OF SAN MATEO COUNTY, CALIFORNIA
}

By Robert K. Mark, Evelyn B. Newman, and Earl E. Brabb 